\title{
Bacterial Abundance - Chlorophyll a Concentration Relationships in Cross River Basin, Southeastern Nigeria: An Evaluation of Empirical Bacterial Abundance - Chlorophyll a Models Using a Multivariate Analysis
}

\author{
Inyang, Aniefiok I*, Antai, Ekpo E, Dan, Monica U \\ Department of Marine Biology, Akwa Ibom State University, Ikot Akpaden Mkpat Enin, Nigeria
}

Email address:

aniefiokinyang@yahoo.com (A. Inyang), ekpo.eyoa@yahoo.com (E. Antai), kyrianmonica@yahoo.com (M. Dan)

To cite this article:

Aniefiok Inyang, Ekpo Antai, Monica Dan. Bacterial Abundance - Chlorophyll $a$ Concentration Relationships in Cross River Basin, Southeastern Nigeria: An Evaluation of Empirical Bacterial Abundance - Chlorophyll a Models Using a Multivariate Analysis. Journal of Water Resources and Ocean Science. Vol. 4, No. 6, 2015, pp. 72-85. doi: 10.11648/j.wros.20150406.11

\begin{abstract}
The relationship between bacteria and chlorophyll $a$ was investigated for three months from July to September, 2008 during flood and ebb tide periods at two sites in the Cross River basin, southeastern Nigeria, to ascertain the reliance of bacteria on autochthonous organic matter. There was no significant difference between flood water and ebb water samples at both stations for the entire variable measured. Bacterial cell abundance showed a weak positive correlation with chlorophyll $a$ concentration at Station $1\left(\mathrm{r}^{*}=0.132, \mathrm{P}>0.05\right)$ and a strong positive correlation at Station $2\left(\mathrm{r}^{*}=0.599, \mathrm{P}>0.5\right)$. The micronutrients at both stations showed a weak negative correlation with chlorophyll $a$ concentration. Linear regression analysis together with standardized coefficient value revealed a high bacteria/chlorophyll $a$ relationship at Station 2 and a weak bacteria/chlorophyll $a$ relationship at Station 1. Principal Component Analysis was applied to the measured variable, and a high correlation was observed between bacterial cell abundance and chlorophyll $a$ concentration at Station 2. A strong reliance of bacteria on chlorophyll $a$ was established at Station 2 whereas Station 1 showed a weak correlation indicating the strong dependence of bacteria on allochthonous organic matter. This bacterial abundance could serve as a good source food for protozoans in transferring energy to classic food chain.
\end{abstract}

Keywords: Bacteria, Chlorophyll $a$, PCA, Protozoan

\section{Introduction}

Bacteria are decomposers, decomposing dead organic matter either on land or in aquatic environment for their food. In the aquatic ecosystem, particulate organic matter or carbon is available to this organism in two ways; land driven (allochthonous materials) and water generated (autochthonous material), mainly derived from phytoplankton, excretory products of other organisms and dead organisms. The assumption that planktonic bacteria depend on phytoplankton in aquatic environments devoid of allochthonous input of organic matter is now widely recognized. This statement is supported by the correlation which exists between bacterial biomass and chlorophyll $a$ concentration $(1,2,3,4,5)$ or between bacterial production and both chlorophyll $a$ concentration and planktonic primary production (6), over a large range of temperature and tropical aquatic environments. Even though there is limited direct evidence, the relationship is often thought to reflect the reliance of planktonic bacteria on algae for their organic carbon requirements. (7), assumed that, up to $50 \%$ of algal primary production is released as Dissolved Organic Carbon (DOC) (8). Algal-released carbon may support up to $95 \%$ of bacterial production $(9,8)$. This co-variation could also hold from similar responses of both groups of organisms to common regulating factors (10), such as the supply of inorganic nutrients $(11,12)$. Some studies have reported strong algal-bacteria coupling, whereas some studies show weak relationship or undetectable $(13,14)$. This is because most of these studies were conducted in systems that received a large amount of allochthonous DOC, and the reduced relative importance of algal-released DOC. For instance, in the Hudson River estuary, (15), found no statistical significant correlation between bacteria density and chlorophyll concentrations, which ranged from about $4-15 \mu \mathrm{gl}^{-1}$. In contrast, several cross-system studies detected significant correlations 
between algal-released DOC and bacterial density. Its chlorophyll concentration ranged from $0.2-189 \mu \mathrm{gl}^{-1}(1) ; 0.05$ $120 \mu \mathrm{gl}^{-1}(2)$; and less than $1 \mu \mathrm{gl}^{-1}$ to more than $100 \mu \mathrm{gl}^{-1}$ (6). Bacterial carbon can often exceed that of the phytoplankton carbon in low chlorophyll $a$ waters, and is commonly $2-3$ times greater $(16,17)$. This is due to reliance of bacteria on allochthonous DOC. (18), found a positive relationship between algae and bacteria in streams. In a comparison of 69 streams, (12) found that epilithic bacterial numbers were related to chlorophyll concentration over a broad range $(<1$ to $>$ $100 \mu \mathrm{gcm}^{-2}$ ) but such a co-variation was not apparent when only streams with low chlorophyll concentration were included (< $5 \mu \mathrm{gcm}^{-2}$ ). (19), found a positive co-variation between chlorophyll concentrations and epilithic bacteria number in one stream and negative relationship in another stream in the same watershed. It is in this disparity that this study was carry out in this ecosystem to ascertain if there will be any relationship between bacterial density and chlorophyll $a$ concentrations. The significance of this study was to reveal the important of carbon to bacteria population in this area.

\section{Materials and Methods}

\subsection{Study Area}

The study areas located in Figure 1 are; $\left(040^{\circ} 57^{\prime} \mathrm{N}, 080^{\circ} 18^{\prime}\right.$ E), Station 1 and $\left(040^{\circ} 45^{\prime} \mathrm{N}, 080^{\circ} 35^{\prime} \mathrm{E}\right)$, Station2. Cross River takes its origin from Oban hills of the south eastern Nigeria and meanders south-north. It is one of the tidal tributaries of the Cross River Estuary draining through heavily forested land scape of south-eastern Nigeria with catchment area of approximately $16662 \mathrm{~km}^{2}$. Cross River Estuary is the largest estuary along the Gulf of Guinea $(20,21)$ covering an estimated area of $54,000 \mathrm{~km}^{2}$ and $39,000 \mathrm{~km}^{2}$ in Nigeria while the remaining $14,000 \mathrm{~km}^{2}$ lies in Cameroon (20). It also has a long coastline with fringing mangrove and a characteristic muddy bottom. It is the largest in the West African sub-region and is approximately $25 \mathrm{~km}$ wide at the mouth and more than $440 \mathrm{~km}$ long with a tidal flushing of 1.83 billion $\mathrm{cm}^{3}$ per day (20). Its climate and hydrology have been reported by $(22,23)$. The average temperature of the estuarine surface water is $26.7^{\circ} \mathrm{C}$. The river discharge upstream (Itu) is $879 \mathrm{~m}^{3} \mathrm{~s}^{-1}$ (dry season) and $2533 \mathrm{~m}^{3} \mathrm{~s}^{-1}$ in wet season (24). Nypa palms with some dotted mangrove plants fringing the coastal waters and other inundation. The local climate of this area is characterized by typical humid regions of southern Nigeria, with a wet season from April - October, and dry season from November - March each year. As in other riverine area, settlement of people and location of industries close to the coast is not excepted. Coastal dwellers engaged in both commercial and artisanal fishery activities and other activities such as logging, sand mining, and petty trading. Station 1 is noted for a commercial boat activity that normally conveys people to Oron town.

\subsection{Hydroclimatic Analysis}

At each location, surface water samples were collected by hand-fill method on each occasion with respect to flooding and ebbing tides, once a week for three months, with a sterile $1 \mathrm{~L}$ plastic bottle. Surface water temperatures were measured insitu using hand-held seaward immersion thermometer with a range value of -10 to $110^{\circ} \mathrm{C}$ and with a percentage error of $\pm 1 \%$. The collected water sample was transported to the laboratory in an ice chest within two hours. Nitrate, phosphate and chlorophyll $a$ were analyzed as described by (25).

\subsection{Estimation of Bacterial Cell Abundance}

From the $1 \mathrm{~L}$ surface water sample, $250 \mathrm{~mL}$ were subsample each. The subsample was placed in larger beaker, thereafter were sized fraction using negative filtration method. $1 \mathrm{ml}$ replicate of each sample was diluted to $10^{-4}$ for subsequent analysis. $1 \mathrm{ml}$ of each replicate was incubated for three hours thereafter subsample for analysis. Bacterial cells present in the subsample were determined directly by epiflorescence microscope using 4, 6, diaminido-2 -phenyl indole (DAPI) as described by (26).

\subsection{Statistical Analysis}

Statistical analysis was carried out with the aid of XLSTAT (2014 version), SPSS (version 17.0) and Microsoft Excel (2010 version). $\mathrm{T}$ - test analysis was used to ascertain the significant difference between flood water sample and ebb water sample for all the variables. Pearson correlation coefficient was used to evaluate relationship between bacterial cells abundance and some other environmental variables (chlorophyll $a$ concentration, nitrate concentration, phosphate concentration and surface water temperature). Principal Component Analysis (PCA) was used to authenticate the correlating behavior between variables and especially with bacteria. Linear regression analysis was used to model a quantitative dependent variable (bacterial cell abundance) with chlorophyll $a$ concentration and with other variables. Since there was no significant difference $(\mathrm{P}<0.05,0.01)$ between flood water sample and ebb water sample at both stations for the entire variables measured, therefore $\mathrm{N}=22$ in all the statistical analysis used.

\section{Results}

The summary statistics for station 1 and station 2 are given in table 1 , while the variation in the measured variables is given in figure 2 to figure 5 in respect to flood tide and ebb tide water sample. $\mathrm{T}$ - test analysis showed no significant difference between flood water sample and ebb water sample at both stations for the entire variables measured $(\mathrm{P}<0.05,0.01)$.

However, the Pearson correlation matrix for the entire measured variables is given in table 2 . Thus, bacterial cell abundance showed a strong negative correlation with phosphate concentration at station $1\left(\mathrm{r}^{*}=-0.587, \mathrm{P}<0.05\right)$ and a weak positive correlation with chlorophyll $a$ concentration $\left(\mathrm{r}^{*}=0.132, \mathrm{P}<0.05\right)$. At station 2 , bacterial cell abundance showed a strong positive correlation with chlorophyll $a$ concentration $\left(\mathrm{r}^{*}=0.599, \mathrm{P}<0.05\right)$ and at station 1 , it showed a weak positive correlation with nitrate concentration $\left(\mathrm{r}^{*}=\right.$ 
$0.389, \mathrm{P}<0.05)$. The micronutrients variables at both stations showed a weak negative correlation with chlorophyll $a$ concentration.

Moreover, the linear regression plot for bacteria and chlorophyll $a$ concentration together with standardized coefficient value for both stations are given in Figure 6 to Figure 13. At station 1, the standardized coefficient value for bacteria/chlorophyll $a$ relationship showed a lower value $(\beta=0.132)$ whereas at station 2 , a higher value was recorded $(\beta=0.599)$.

Furthermore, the Principal Component Analysis (PCA) was applied to the five variables collected during the period of sampling (bacteria abundance, chlorophyll $a$ concentration, nitrate concentration, phosphate concentration and surface water temperature). The highest correlation exists between bacterial cell abundance and chlorophyll $a$ concentration at station 2 whereas at station 1 bacterial cell abundance showed a negative correlation with phosphate concentration Figure 15 and Figure 17. A scree plot presented in Figure 14 and Figure 16 shows the sorted eigenvalues from large to small as the function of principal components number for station 1 and station 2 respectively. Results of factor analysis including factor-loading matrix, eigenvalues, variability and cumulative variance values are given in table 3 . The factor analysis derived from PCA generated three significant factors which explained $84.43 \%$ of the variance in data sets. Factor 1 (F1) explained $43.91 \%$ and $36.58 \%$ of the variance at station 1 and station 2 respectively. The $\mathrm{F} 1$ revealed a high positive loading with respect to bacterial cell abundance and surface water temperature, and a high negative loading with phosphate concentration which were $0.819,0.674$ and -0.800 respectively for station 1 . At station $2, \mathrm{~F} 1$ revealed a high positive loading with respect to bacterial cell abundance, chlorophyll $a$ concentration and surface water temperature which were $0.846,0.536$ and 0.676 respectively.

\section{Discussion}

The stipulated period of study coincided with the wet season normally encountered in Nigeria that is from April to October. (27) reported a major influence of this season on the aquatic physiochemical characteristics and periphyton community. Surface water temperature showed a little fluctuation at both stations. $(28,29)$ reported a positive effect of temperature on aquatic bacterial production and growth rate. Therefore, the observed highest value of surface water temperature in the month of September 2008, during flood tide at both stations could be as a result of time of collection and specific heat capacity of the water that could speed up bacterial multiplication and growth. The increased value of chlorophyll $a$ concentration in the month of July and August at both station coincided with the increased level of the micronutrients in this month. The weak Pearson correlation matrix of chlorophyll $a$ with the micronutrients at both stations could explain the importance of flood water discharge and storm water in the introduction of phyto-planktonic cells, and the time lag in the remineralization of the introduced nutrients into the system. A strong relationship between phosphorus, chlorophyll and water clarity have been reported for fresh water systems around the world (30). Thus the weak chlorophyll a - phosphate relationship observed in station 1 could explain the important of this nutrient to phytoplankton growth and been a limiting one in this area.

However, increase in bacteria population in water after rainfall has been recorded frequently. At station 1 and station 2, bacterial population may hold a positive correlation with precipitation if noted. It is likely that nutrients brought into the river basin were rapidly utilized, so a direct effect of rainfall was confined to areas near the inflows. After every heavy rainfall, an immediate change in the bacterial population could be detected. During this sampling period, there was unusual high rainfall. The observed peaks at station 1 and station 2 could be attributed to a combined effect of large amount of organic matter available for bacterial decomposition together with the effect of inflow of nutrients and bacteria on bacterial cells populations near to the shore where samples were taken. The bacterial cell abundance correlates significantly with micronutrients level mostly at station 1 than station 2 . This corresponds to increase in bacterial cell abundance with nutrient level in the surface water at both study sites. The high abundance of bacterial cell was due to availability of carbon source. Bacteria could sever as a good food material for the protozoans thereby transferring energy back into the classic food chain.

Heterotrophic bacteria in coastal water have two sources of organic matter at their disposal - local ones comprising excreta and the remains of phytoplankton and zooplankton; and the external ones in the form of terrigenous, allochthonous organic matter. Therefore bacteria could depend directly on phytoplankton itself, or excreted products from animals (31) or indirectly from allochthonous input. It is likely, however, that both mechanisms occur simultaneously.

The release of dissolved organic carbon (DOC) by healthy phytoplankton is a small percentage of the photosynthetic rate $(5-10 \%),(32)$. Considering this low release rate of DOC makes it necessary for bacteria to depend on allochthonous input of DOM for their production and multiplication. Therefore, the high abundance of bacterial cells reported at station 1 which correlates weakly with chlorophyll $a$ concentration show a reliance of bacteria on allochthonous input of organic cardon. Its lower standardized coefficient value with chlorophyll $a$ could also confirm their weak relationship. This observation might be attributed to the unusual precipitation that brought enormous allochthonous carbon into the system during the study period. The discharge of large amount of organic matter together with the direct effect of inflow of nutrients and bacterial cells on bacteria population at station 1 may also be a reason for the weak relationship. At station2 the correlation is high indicating the dependency of bacterial cell on chlorophyll $a$ concentration.

In summary, a weak statistical correlation between bacterial cells abundance and chlorophyll $a$ concentration at station 1 confirmed the dependency of bacteria on allochthonous influx of particulate and dissolved organic carbon especially during wet seasons. It is obvious that bacteria population utilized 
organic substrate for its growth which could be phytoplankton exudates or other organic materials. This high bacterial density observed, reflects its percentage biomass that may serve as food source for protists which would in turn serve as food to the next trophic level and thus link the DOC/POM to classic food chain in the environment.

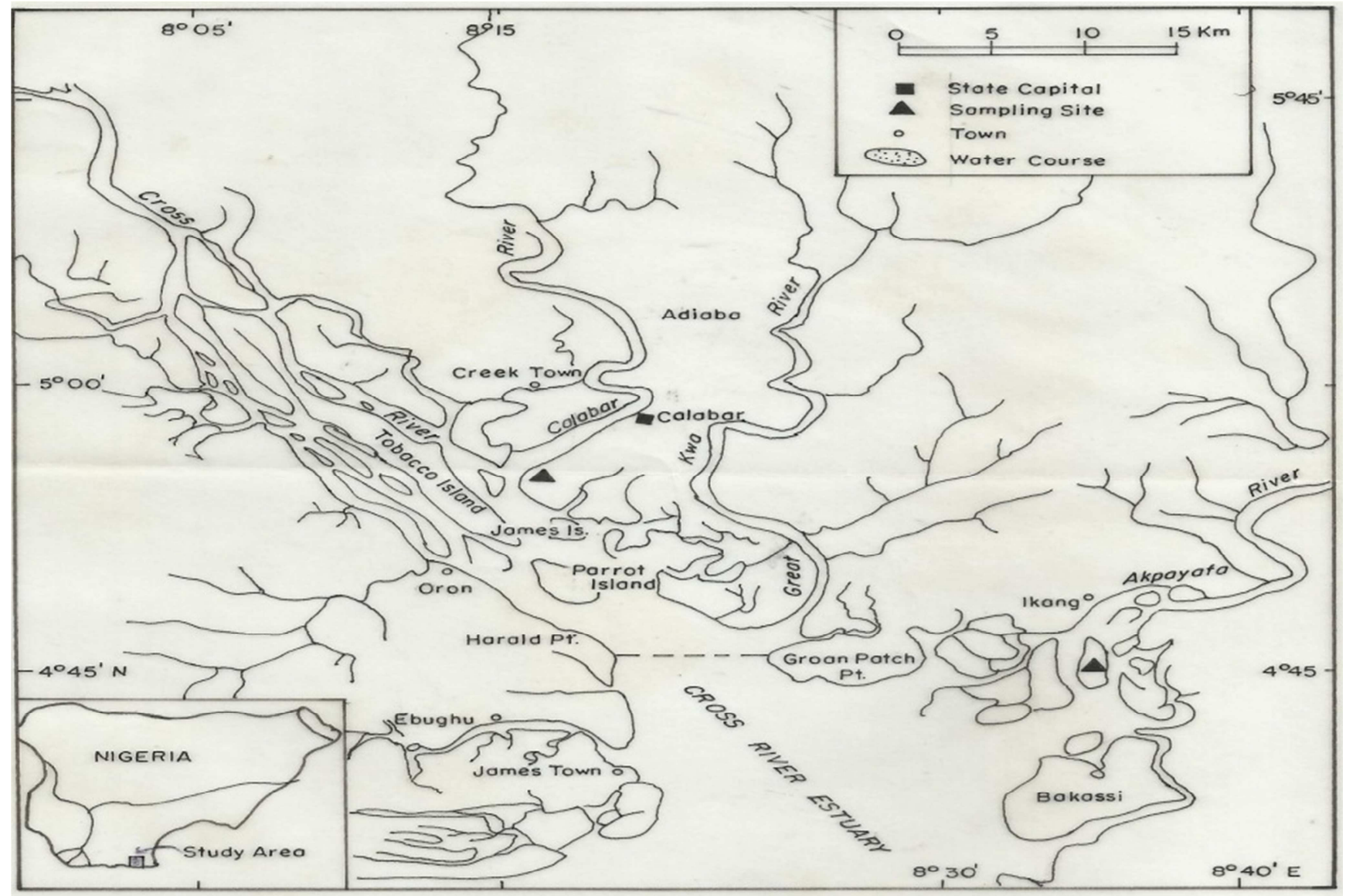

Cross River Estuary and its Tributries showing the Sampling Sites

Figure 1. Map of the cross river basin southeastern Nigeria showing the sampling site.

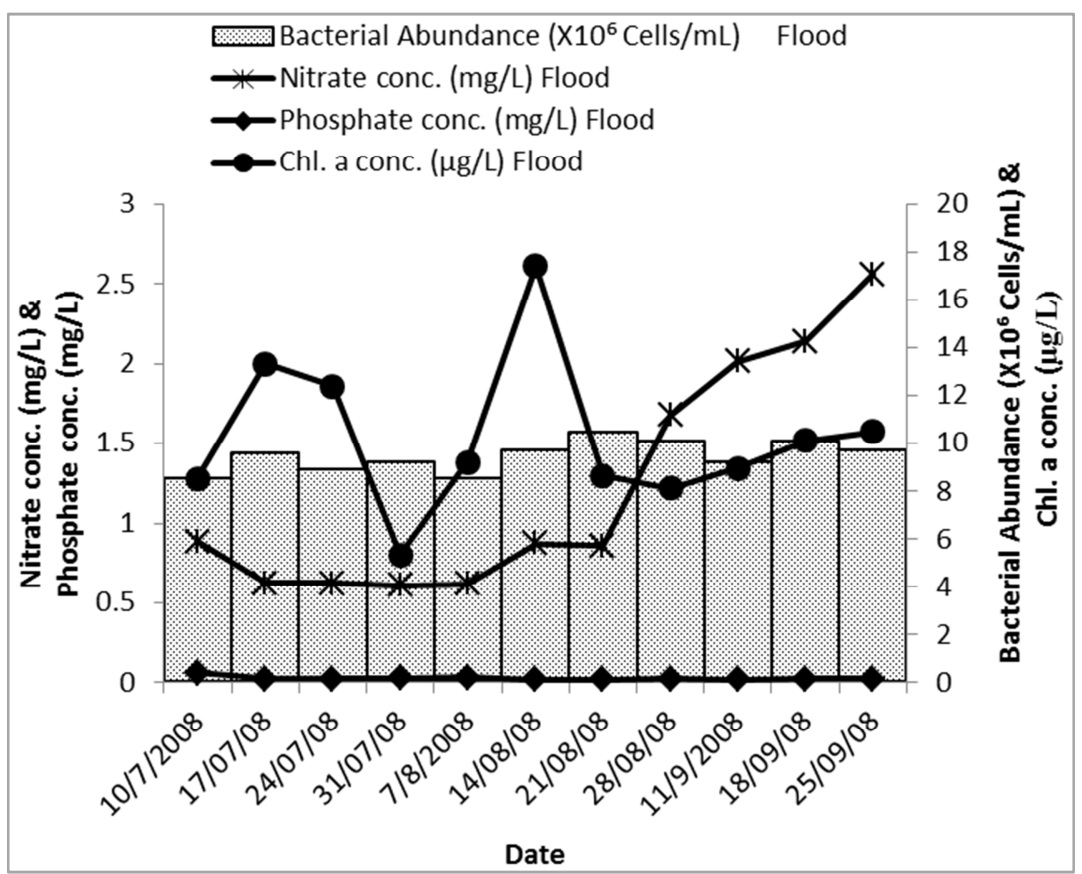

Figure 2. Variation in micro nutrient, chlorophyll a concentration and bacterial cells abundance for station 1 at flood tide from July, 2008 to September, 2008. 


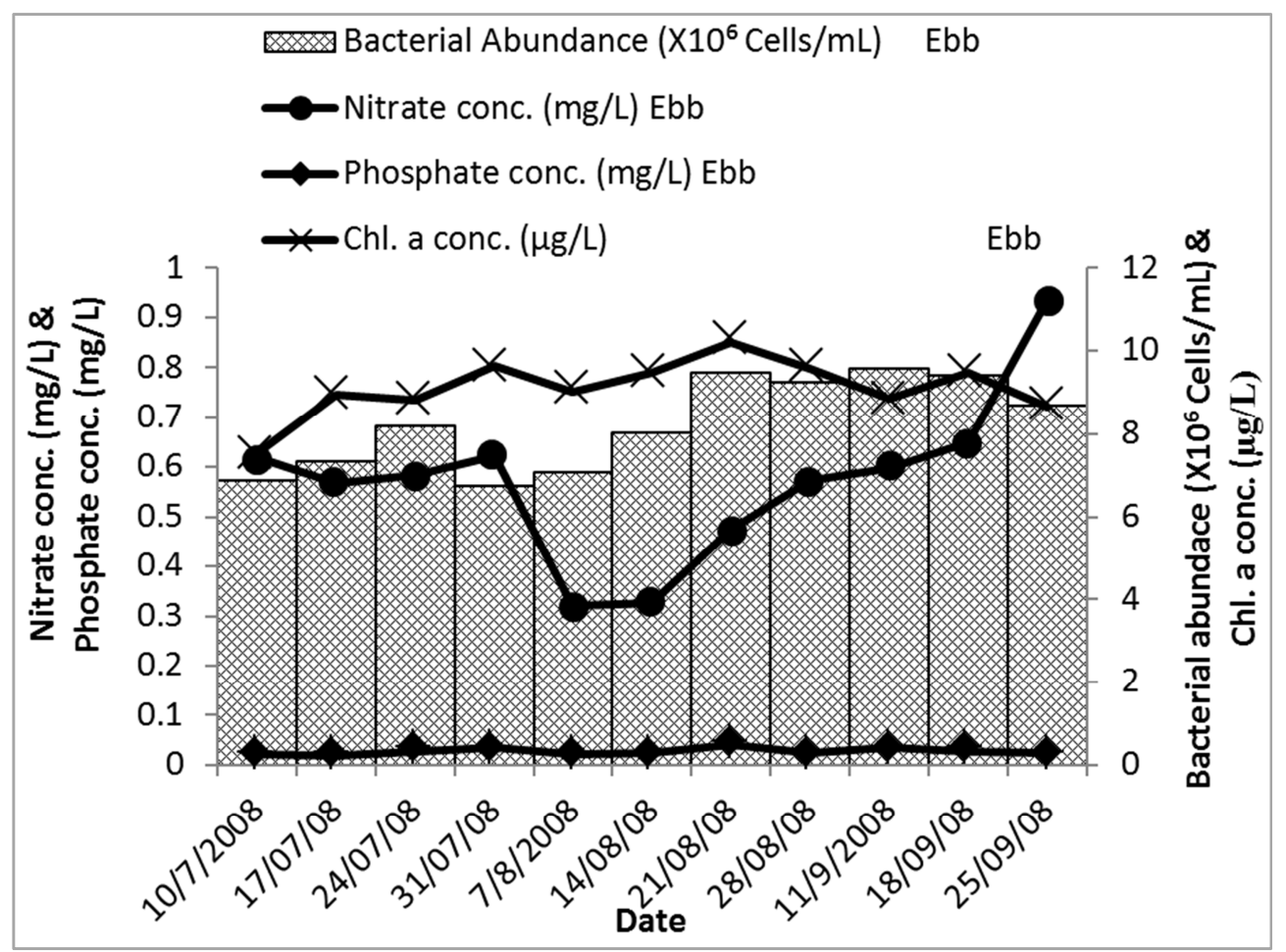

Figure 3. Variation in micro nutrient, chlorophyll a concentration and bacterial cells abundance for station 1 at ebb tide from July, 2008 to September, 2008.

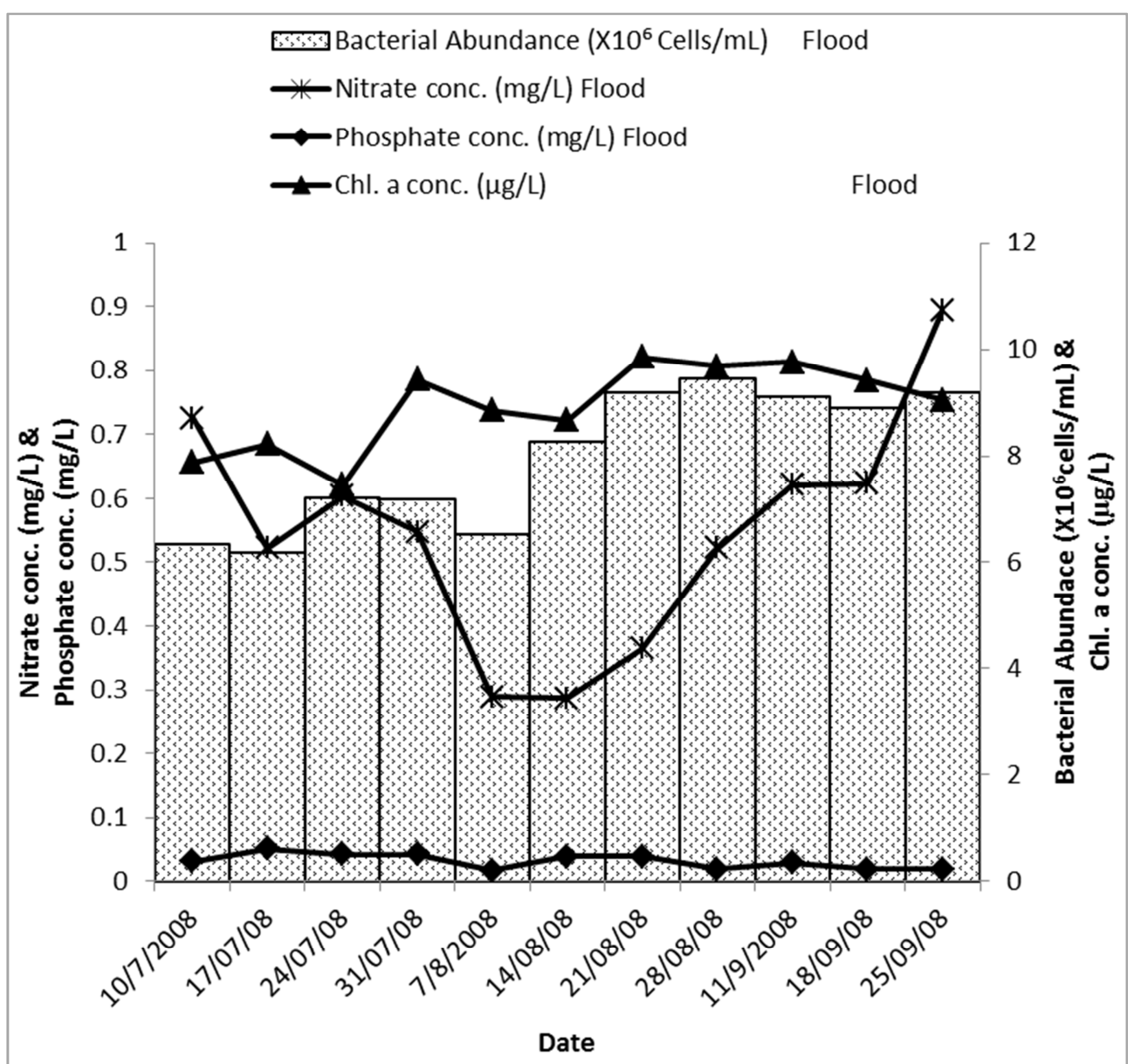

Figure 4. Variation in micro nutrient, chlorophyll a concentration and bacterial cells abundance for station 2 at flood tide from July, 2008 to September, 2008. 


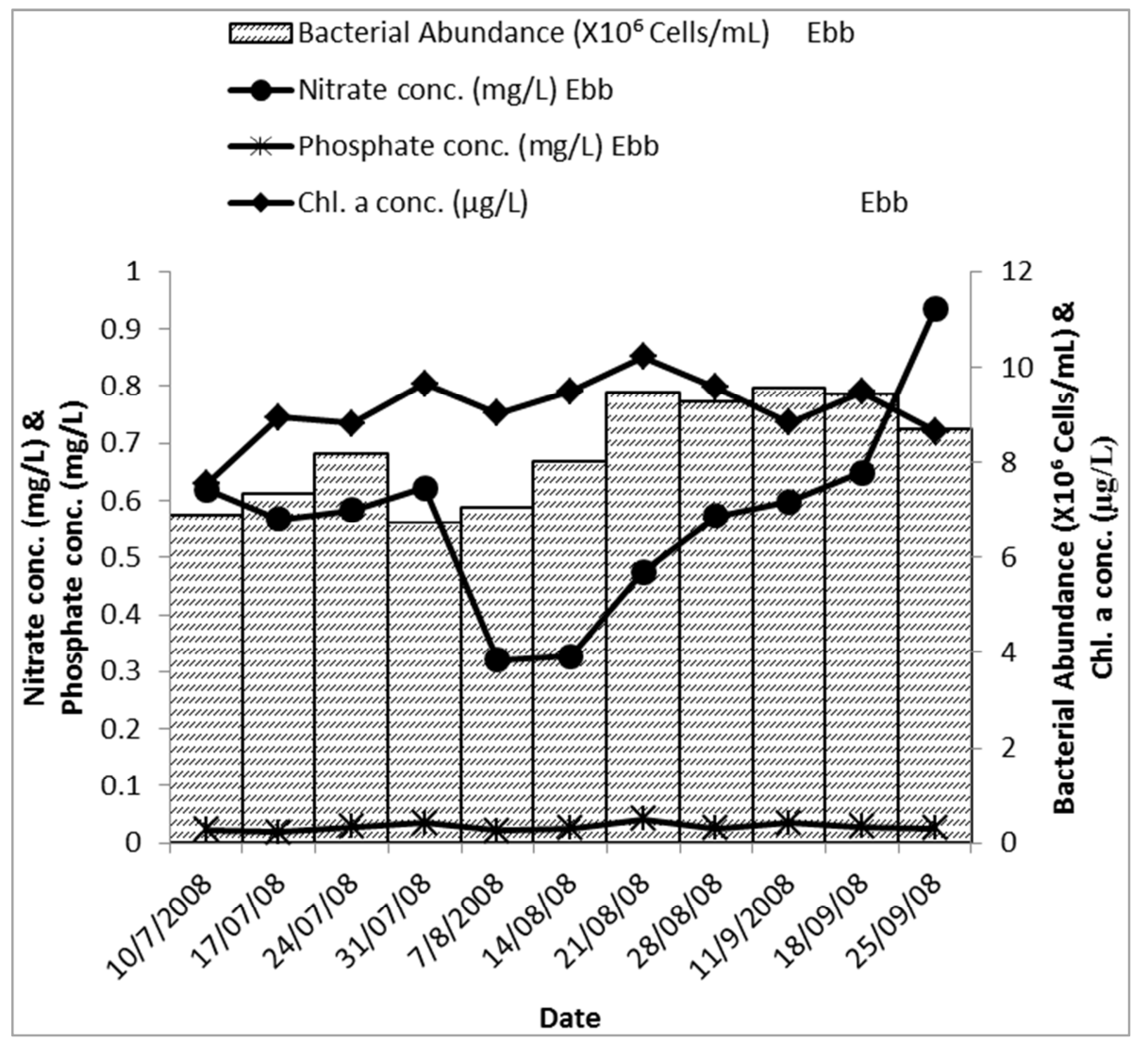

Figure 5. Variation in micro nutrient, chlorophyll a concentration and bacterial cells abundance for station 2 at ebb tide from July, 2008 to September, 2008.

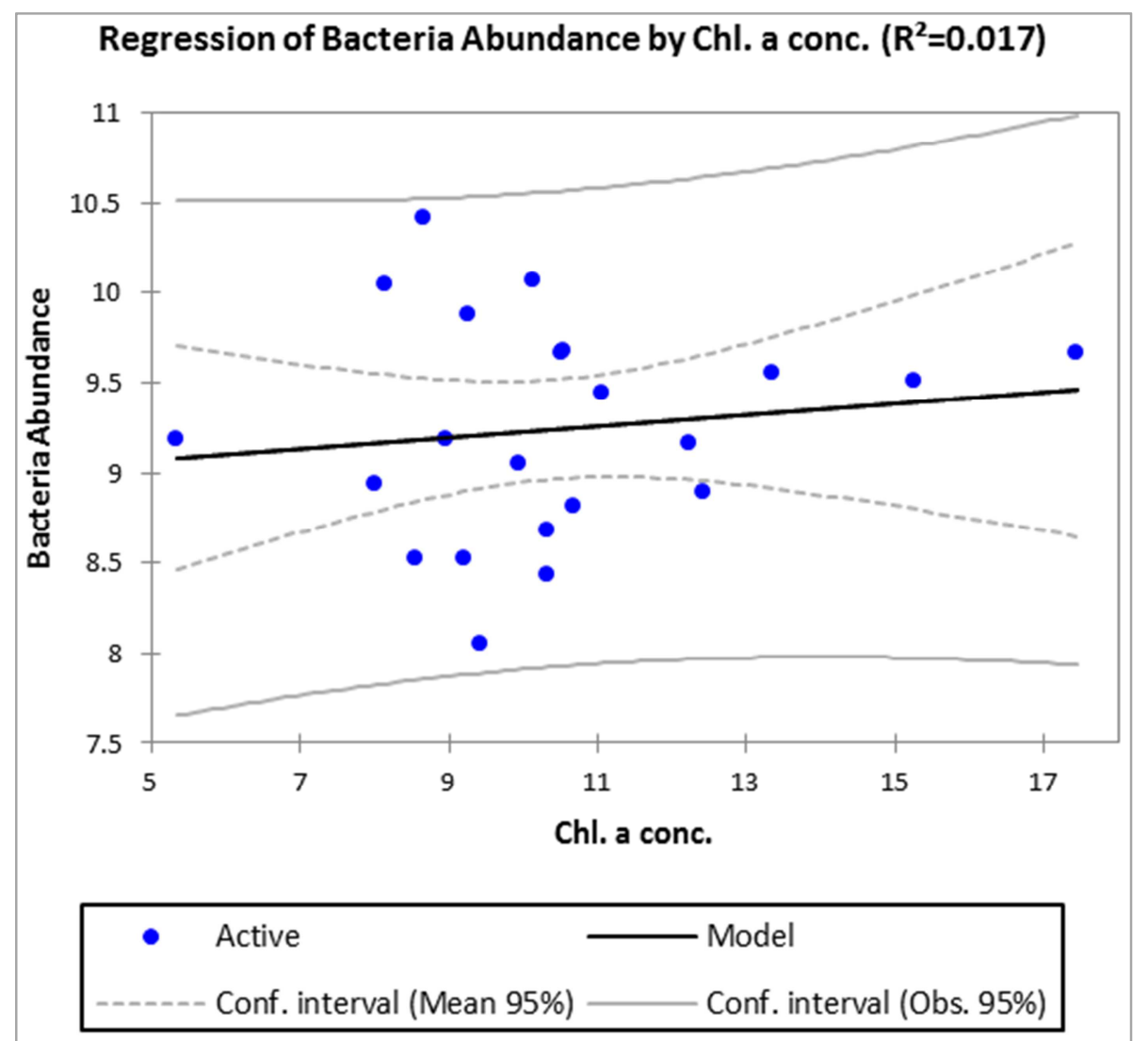

Figure 6. Regressional plot for bacterial cells abundance and chlorophyll a conc. at station 1 from July, 2008 to September, 2008. Bacteria $=8.917+0.0312$ Chl a. $\left\{R^{2}=0.017, r^{*}=0.132, N=22, P<0.05\right\}$. 


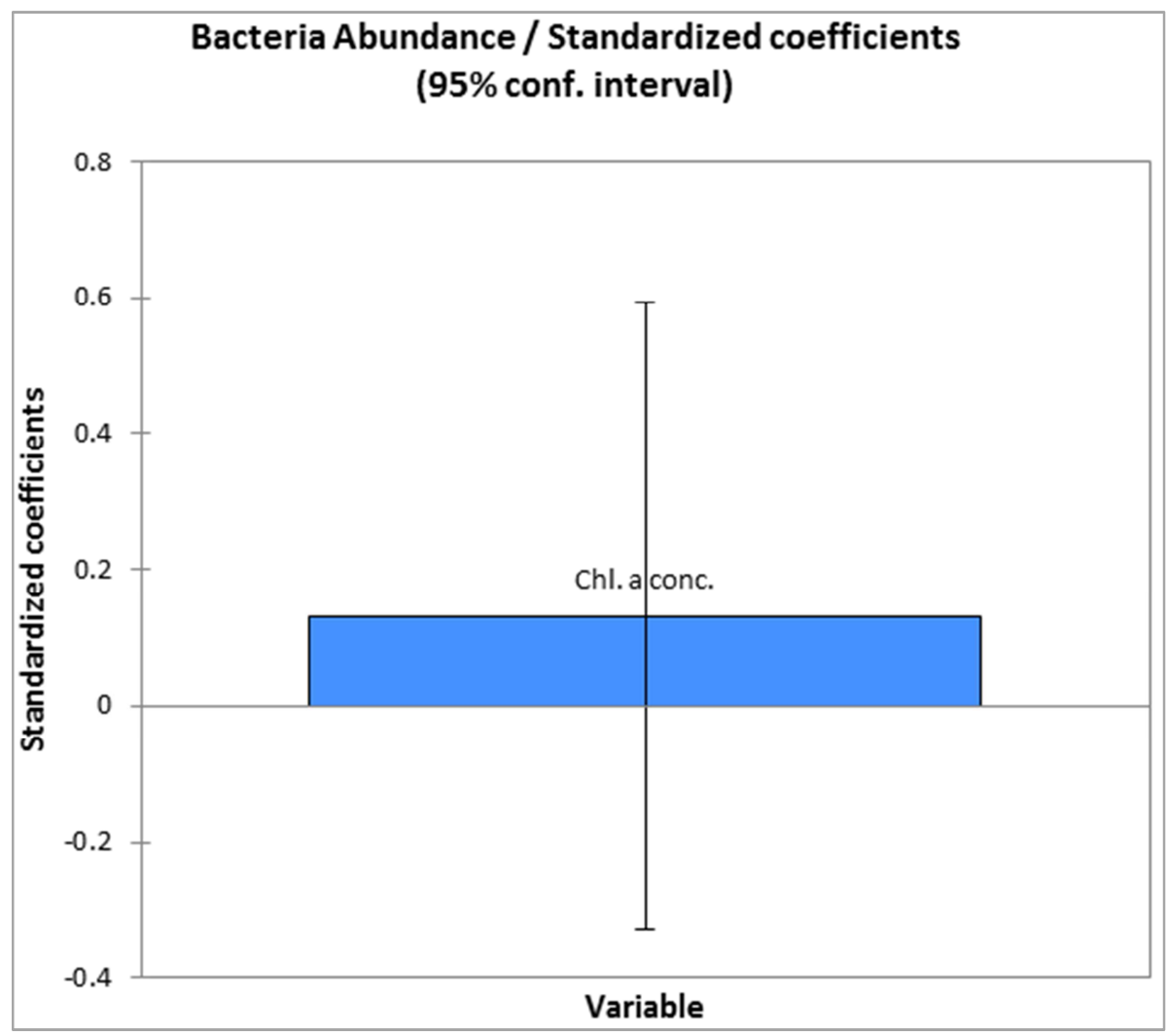

Figure 7. Bacteria/Chl. a standardized plot at station 1 from July, 2008 to September, 2008. \{Standardized coefficient $=0.132$, Standard error $=0.222, t=$ $0.594, \operatorname{Pr}>|t|=0.559$, lower bound $=-0.331$, upper bound $=0.594, N=22$.

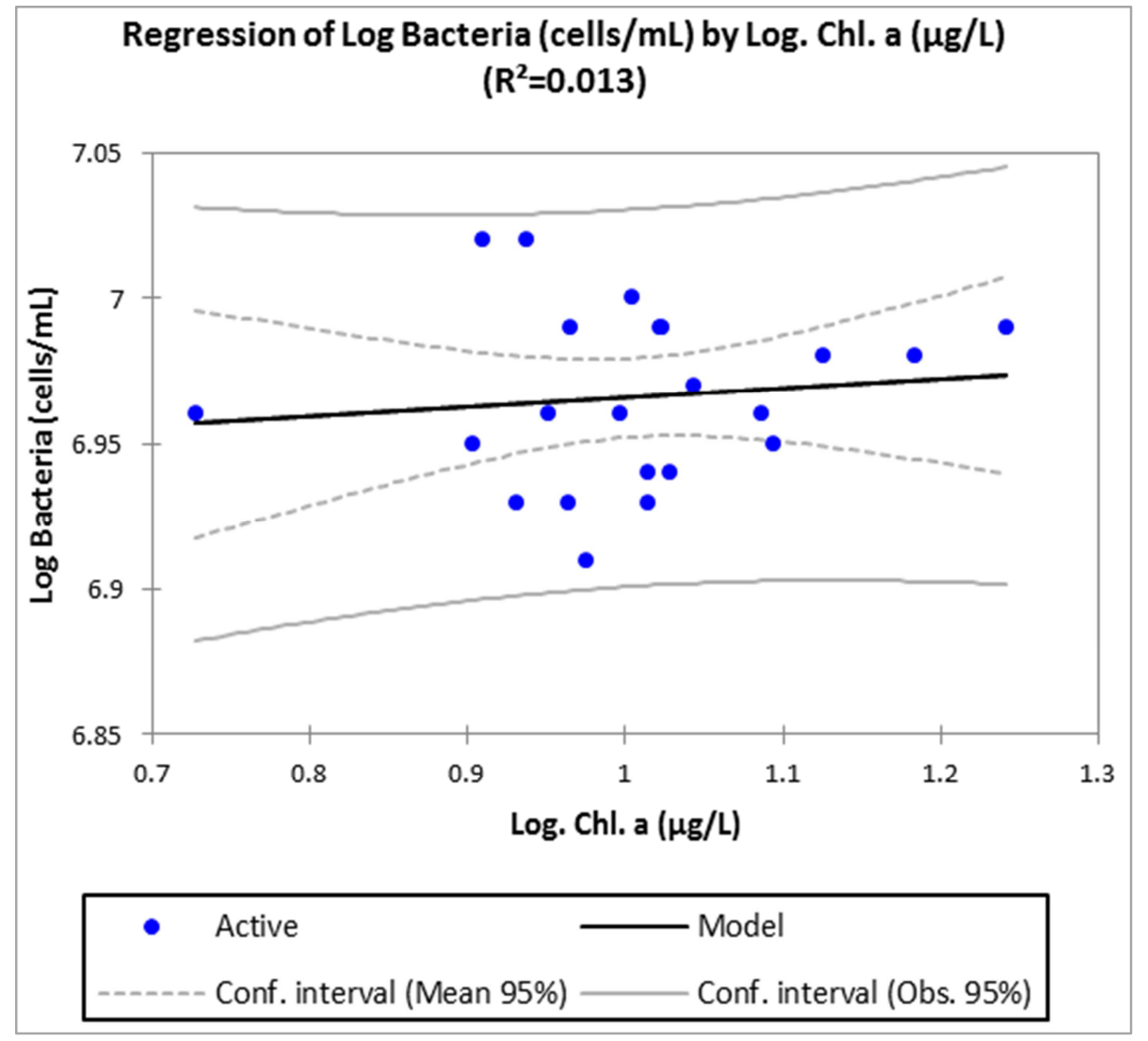

Figure 8. Regressional Log plot for bacterial cells abundance and chlorophyll a conc. at station 1 from July, 2008 to September, 2008. Log. Bacteria $=6.933$ $+0.032 \log$ Chl a $\left\{N=22, P<0.05, r^{*}=0.114, R^{2}=0.013\right\}$. 


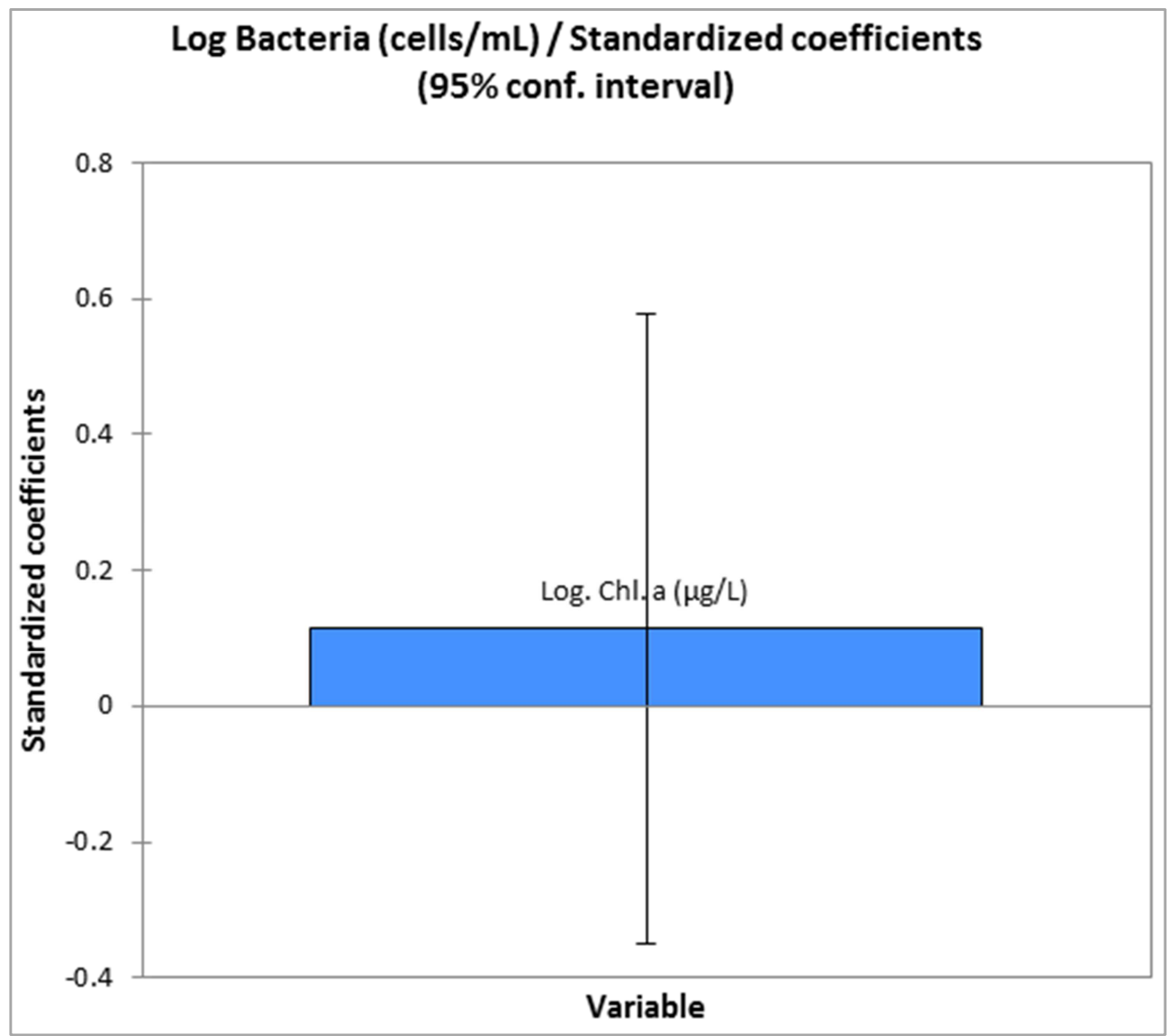

Figure 9. Log Bacteria/Log Chl. a standardized plot at station 1 from July, 2008 to September, 2008. \{Standardized coefficient $=0.114$, Standard error $=$ $0.222, t=0.513, \operatorname{Pr}>|t|=0.614$, lower bound $=-0.349$, upper bound $=0.577, N=22\}$.

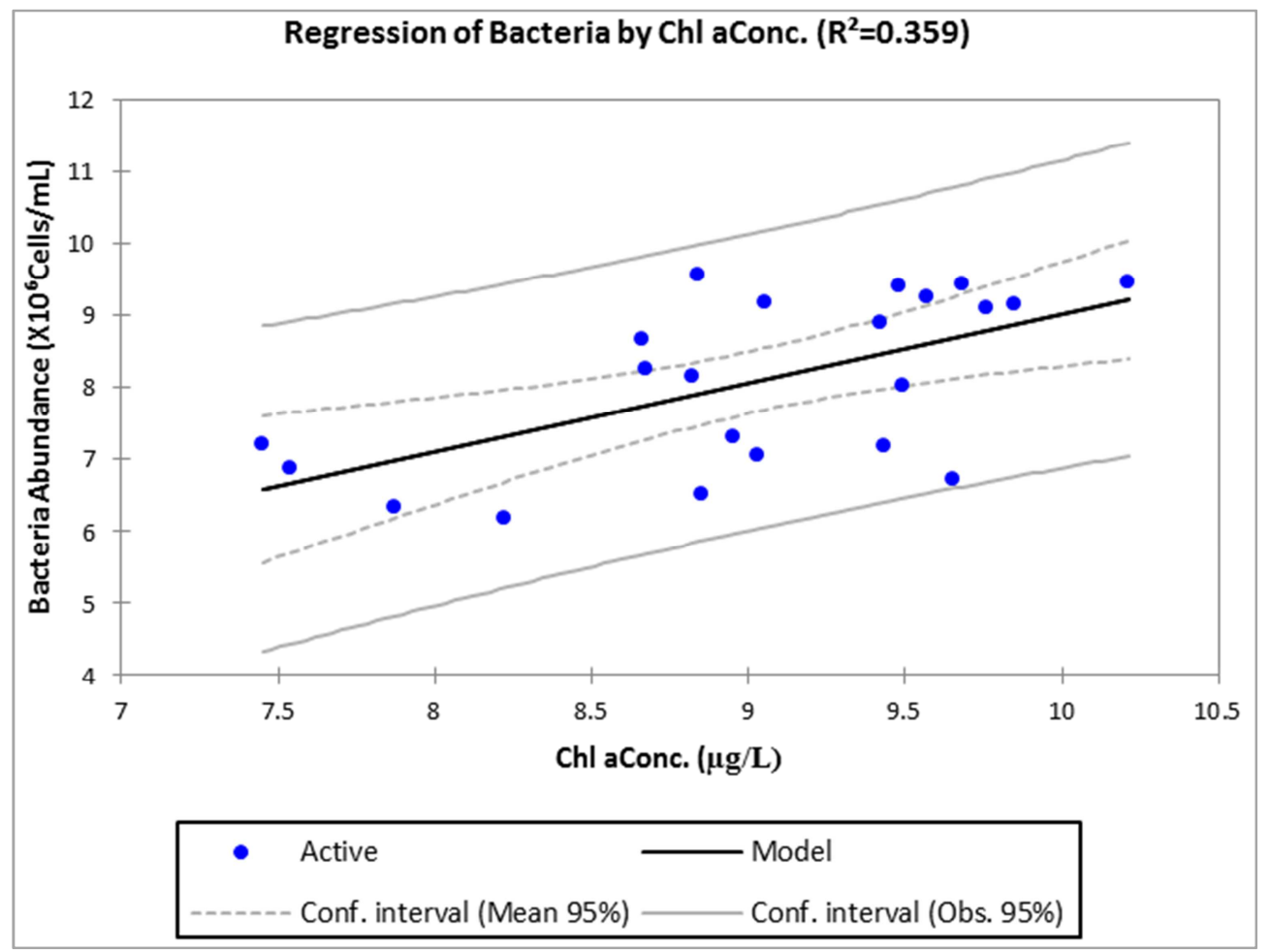

Figure 10. Regressional plot for bacterial cells abundance and chlorophyll a conc. at station 2 from July, 2008 to September, 2008. Bacteria = 0.953Chl. a0.506. $\left\{N=22 ; R^{2}=0.359 ; P<0.05, r^{*}=0.599\right\}$. 


\section{Bacteria / Standardized coefficients}

(95\% conf. interval)

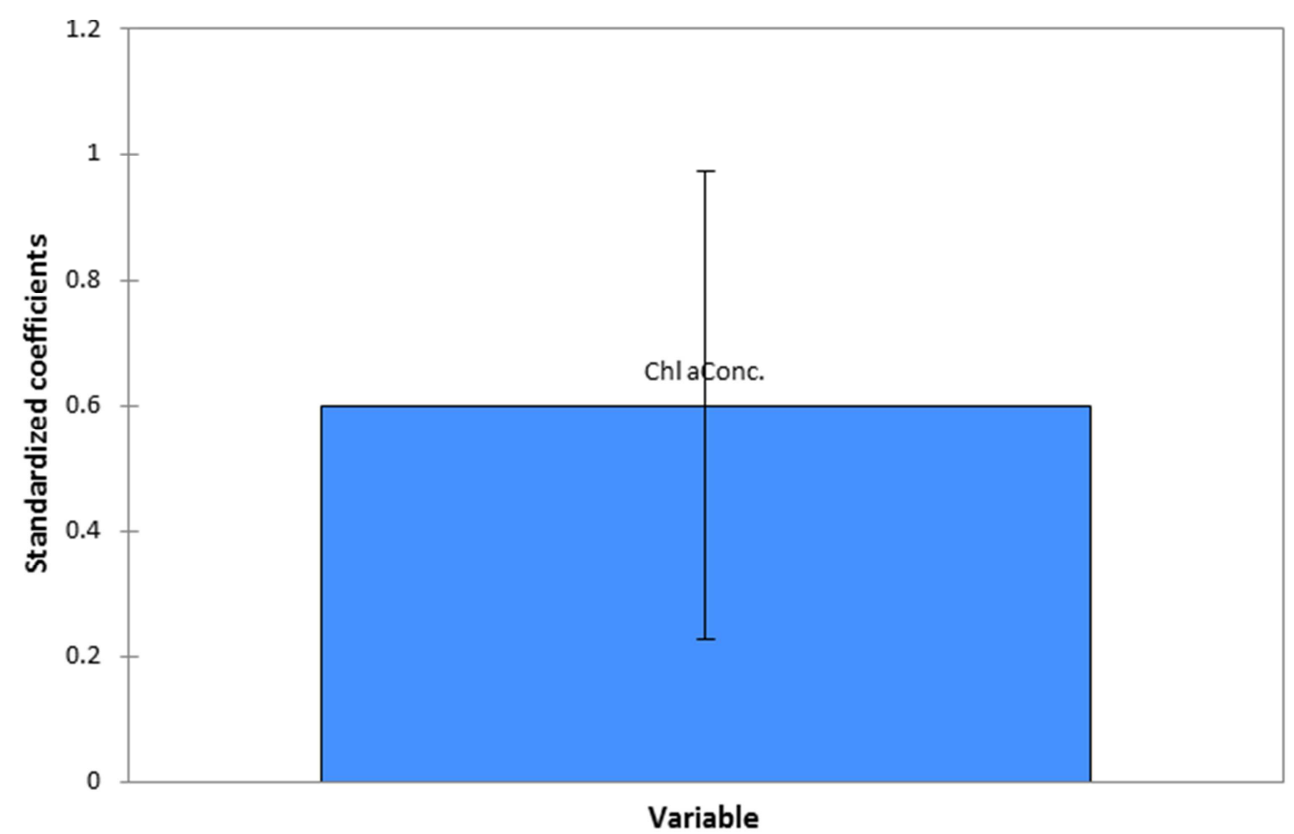

Figure 11. Bacteria/Chl. a standardized plot at station 2 from July, 2008 to September, 2008. $\{$ Standardized coefficient $=0.599, t=3.348, P r>|t|=0.003$, lower bound $(95 \%)=0.226$, upper bound $(95 \%)=0.973, P<0.05$ \}

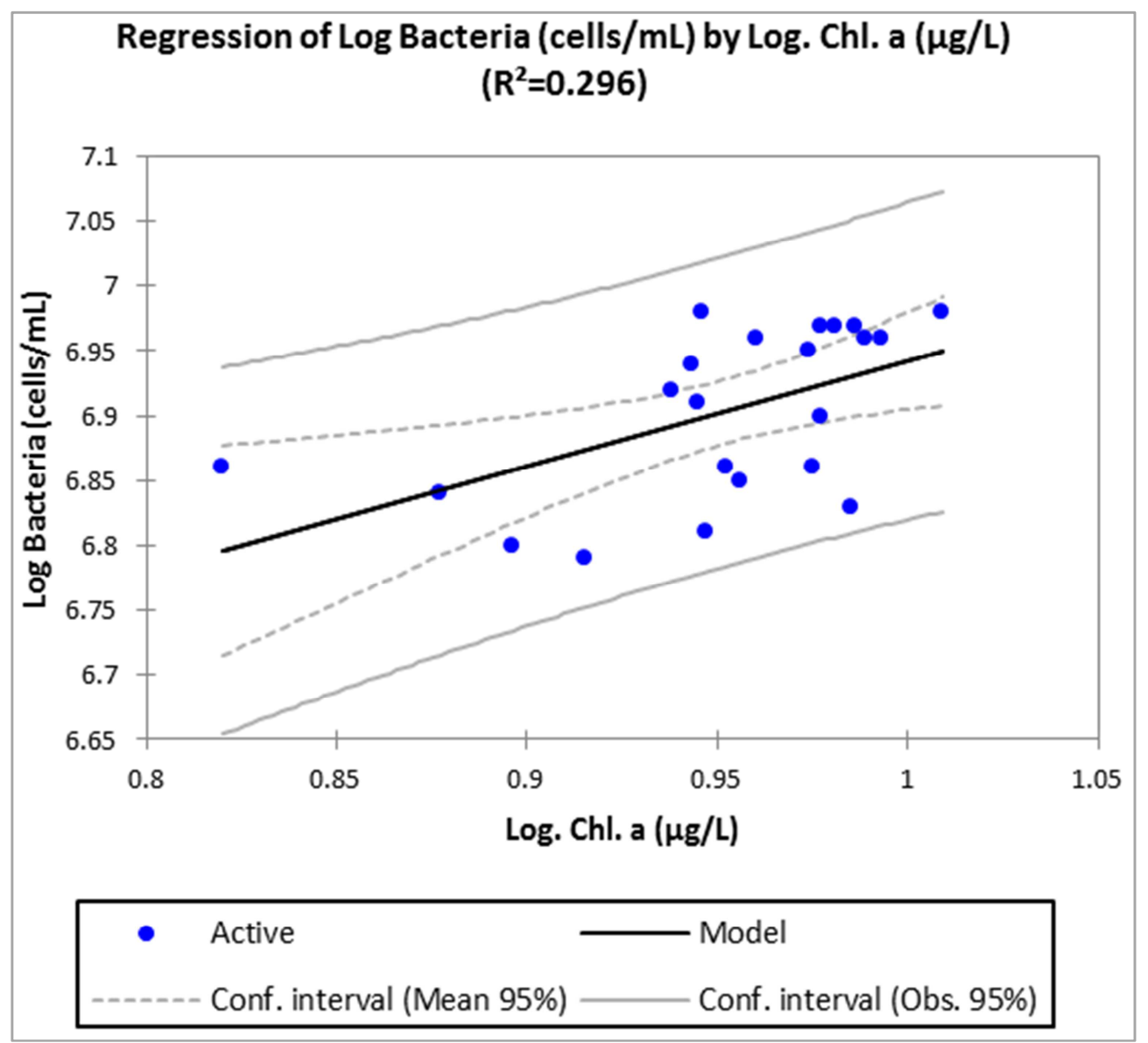

Figure 12. Regressional Log plot for bacterial cells abundance and chlorophyll a conc. at station 2 from July, 2008 to September, 2008. Log Bacteria $=6.129$ $+0.813 \log$ Chl. a $\left\{R^{2}=0.296, N=22, r^{*}=0.544, P<0.05\right\}$. 


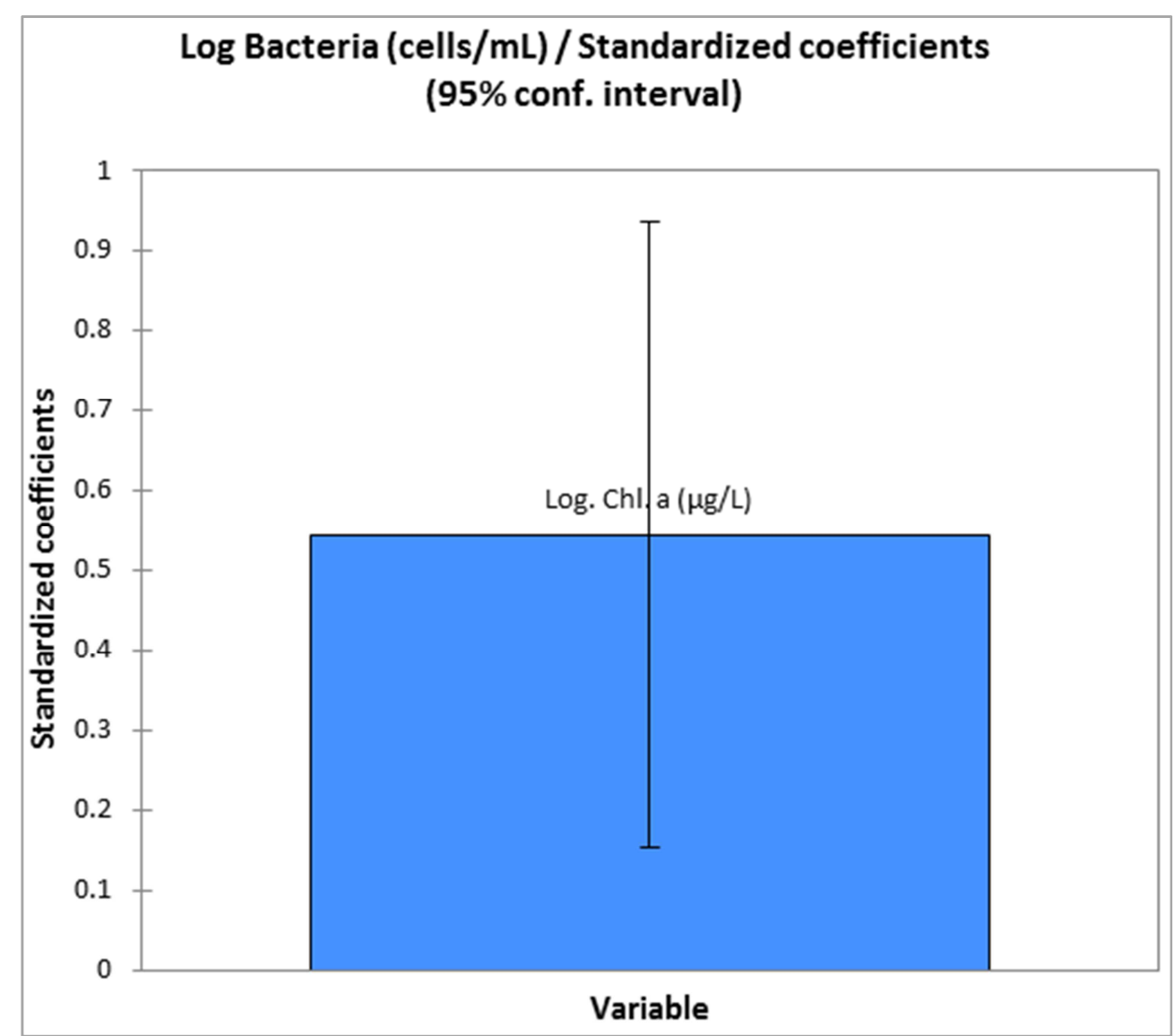

Figure 13. Log Bacteria/Log Chl. a standardized plot at station 2 from July, 2008 to September, 2008. $\{$ Standardized coefficient $=0.544, t=0.188, P r>|t|=$ 0.009 , lower bound $=0.153$, upper bound $=0.935, P<0.05$.

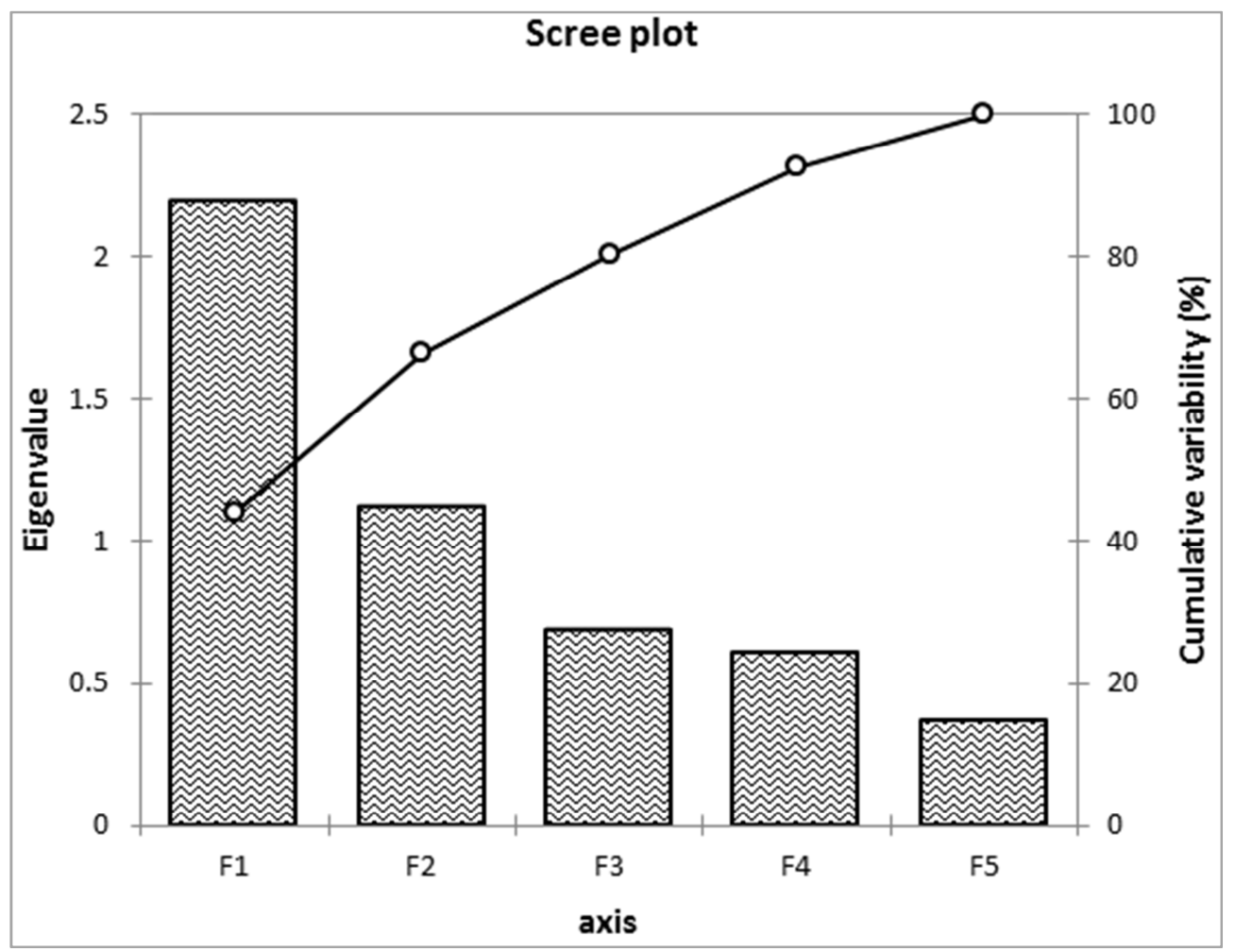

Figure 14. Scree plot of the eigenvalue for station 1 from July, 2008 to September, 2008. 


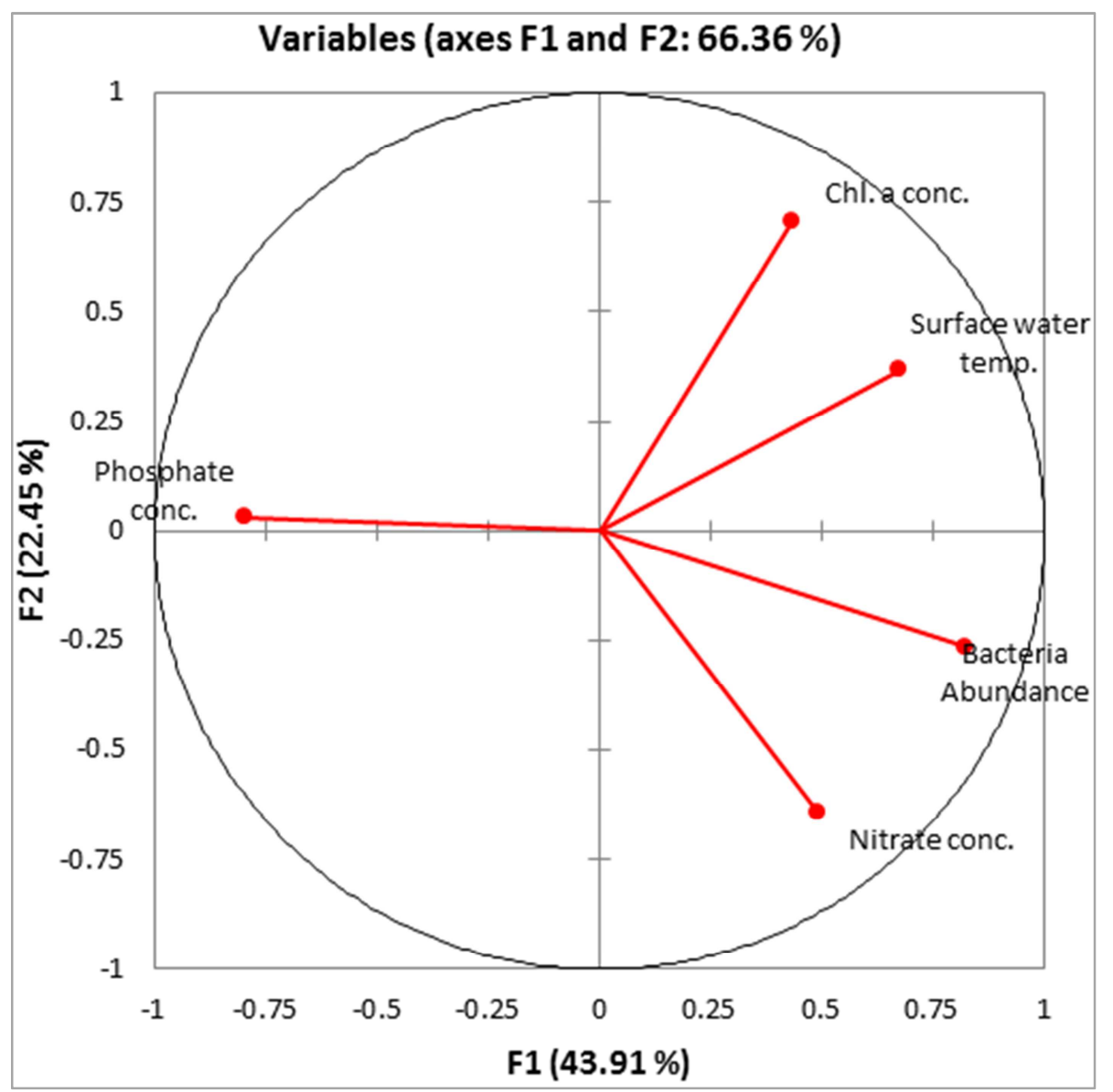

Figure 15. PCA plot of variables for station 1 from July, 2008 to September, 2008.

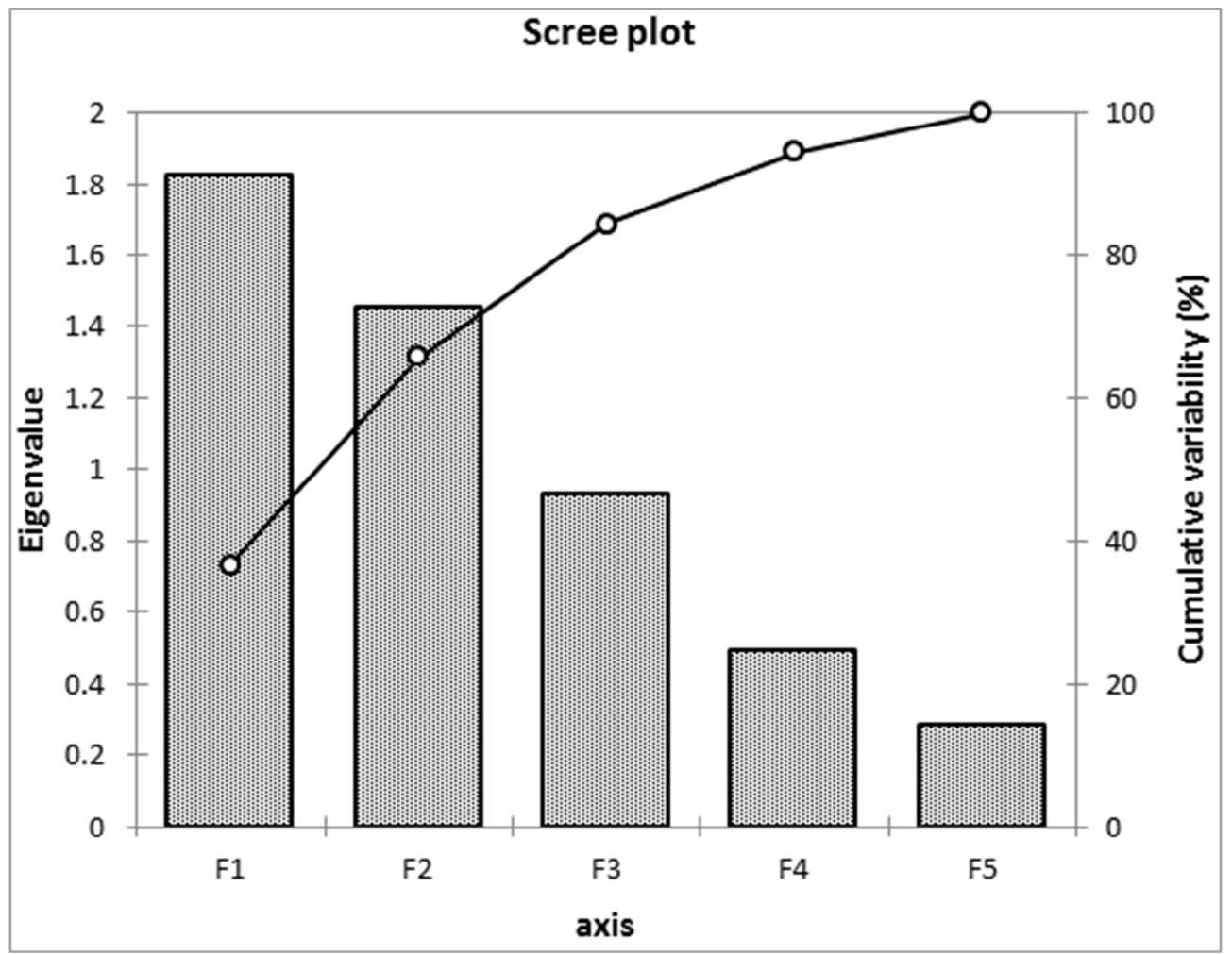

Figure 16. Scree plot of the eigenvalue for station 2 from July, 2008 to September, 2008. 


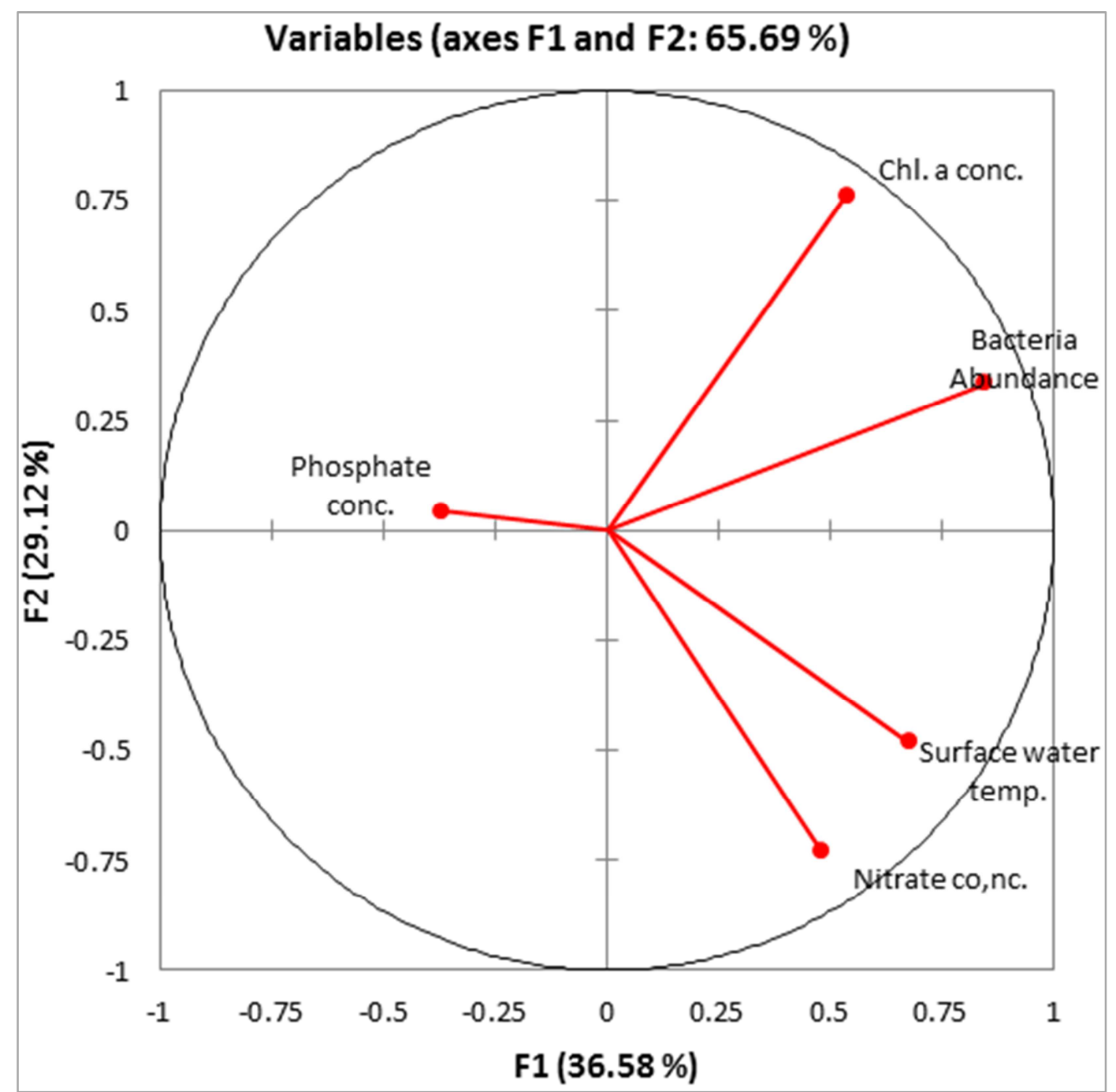

Figure 17. PCA plot of variables for station 2 from July, 2008 to September, 2008.

Table 1. Summary statistics for station 1 and station 2 from July, 2008 to September, 2008.

\begin{tabular}{lllllllll}
\hline & Station1 & \multicolumn{7}{c}{ Station 2 } \\
\hline Variable & Min. & Max. & Mean & Std. Dev. & Min. & Max. & Mean & Std. Dev. \\
\hline Bacterial Abundance & 8.050 & 10.42 & 9.243 & 0.609 & 6.180 & 9.560 & 8.091 & 1.178 \\
Chl. a conc. & 5.340 & 17.430 & 10.441 & 2.568 & 7.450 & 10.210 & 9.022 & 0.741 \\
Nitrate conc. & 0.253 & 2.862 & 1.256 & 0.773 & 0.286 & 0.934 & 0.558 & 0.171 \\
Phosphate conc. & 0.018 & 0.071 & 0.027 & 0.013 & 0.017 & 0.051 & 0.030 & 0.010 \\
Surface water temp. & 25.0 & 30.0 & 27.545 & 1.224 & 25 & 29 & 26 & 0.913 \\
\hline
\end{tabular}

Table 2. Pearson correlation matrix for station 1 and station $2\{N=22, P<0.05\}$.

\begin{tabular}{|c|c|c|c|c|c|c|}
\hline \multirow{6}{*}{ Station 1} & Variables & Bacterial Abundance & Chl. a conc. & Nitrate conc. & Phosphate conc. & Surface water temp. \\
\hline & Bacterial Abundance & 1 & & & & \\
\hline & Chl. a conc. & 0.132 & 1 & & & \\
\hline & Nitrate conc. & 0.389 & -0.014 & 1 & & \\
\hline & Phosphate conc. & -0.587 & -0.247 & -0.249 & 1 & \\
\hline & Surface water temp. & 0.387 & 0.326 & 0.113 & -0.365 & 1 \\
\hline \multirow{5}{*}{ Station 2} & Bacterial Abundance & 1 & & & & \\
\hline & Chl. a conc. & 0.599 & 1 & & & \\
\hline & Nitrate conc. & 0.174 & -0.21 & 1 & & \\
\hline & Phosphate conc. & -0.153 & -0.0093 & -0.132 & 1 & \\
\hline & Surface water temp. & 0.354 & 0.005 & 0.464 & -0.098 & 1 \\
\hline
\end{tabular}

Values in bold are different from 0 with a significance level alpha $=0.05$ 
Table 3. Factor-loadings, eigenvalues, variability and cumulative value for station 1 and station 2.

\begin{tabular}{|c|c|c|c|c|c|c|}
\hline & F1 & F2 & F3 & F1 & F2 & F3 \\
\hline Bacterial Abundance & 0.819 & -0.263 & -0.204 & 0.846 & 0.335 & 0.151 \\
\hline Chl. a conc. & 0.434 & 0.710 & 0.500 & 0.536 & 0.763 & 0.07 \\
\hline Nitrate conc. & 0.492 & -0.642 & 0.552 & 0.484 & -0.727 & 0.047 \\
\hline Surface water temp. & 0.674 & 0.370 & -0.170 & 0.676 & -0.482 & 0.231 \\
\hline Eigenvalue & 2.195 & 1.123 & 0.692 & 1.829 & 1.456 & 0.937 \\
\hline Variability (\%) & 43.908 & 22.450 & 13.844 & 36.576 & 29.117 & 18.73 \\
\hline
\end{tabular}

$\{\mathrm{N}=22\}$

\section{Acknowledgement}

I would like to appreciate Dr. E.E. Antai, Institute of Oceanography, University of Calabar for his encouragement and support throughout the period I carried out this work, and to all the laboratory staff of the Biological Oceanography Department, University of Calabar, Nigeria for their support during the analysis.

\section{References}

[1] Aizaki M, Otsuki A, Fukushima T, Hosomi M and Muraoka L, 1981. Application of Carlson's trophic state index to Japanese lakes and relations between the index and other parameters. Verhandlungen des Internationalen Verein Limnologie 12: pp. $675-681$.

[2] Bird DF and Kalff J, 1984. Empirical relationships between bacterial abundance and chlorophyll concentration in fresh and marine waters. Canadian Journal of Fisheries and Aquatic Sciences 41: pp. 1051 - 1023.

[3] Rob Smith, and Julie Hall, 1997. Bacterial abundance and production in different water masses around South Island, New Zealand. Marine \& Freshwater Research 31: pp. $515-$ 524 .

[4] Kapiris K, Kormas, KA, Maria T, and Nicolaidou A, 1998. Quantitative relationships between phytoplankton, bacteria \& Protists in an Acgean semi-enclosed embayment of Maliakos Gulf, Greece. Aquatic Microbial Ecology 15: pp. 255 - 264.

[5] Tada K, Monaka K, Morishita M, and Hashimoto T, 1998. Standing stocks and Production Rate of Phytoplankton and Bacteria in the Seto Inland Sea, Japan. Oceanography 54: pp. $285-295$.

[6] Cole JJ, Findlay S, and Pace ML, 1988. Bacterial production in fresh and salt water ecosystems: a cross-system over-view. Marine Ecology Progress Series 43: pp. 1 - 10.

[7] Gasol JM, and Duarte CM, 2002. Comparative analyses in aquatic microbial ecology: how far do they go? FEMS Microbial Ecology 31: pp. 99 - 106.

[8] Lyche A, Adersen T, Christoffersen K, Hessen DO, Hansen PHB, and Klysner A, 1996. Mesocosm tracer studies. 2. The fate of primary production and the role of consumers in the pelagic carbon cycle of a mesotrophic lake. Limnology and Oceanography 41: pp. 475 - 487.

[9] Coveney MF, 1982. Bacterial uptake of photosynthetic carbon from freshwater phytoplankton. Oikos 38: pp. 8-20.
[10] Coveney MF, and Wetzel RG, 1995. Biomass, Production, and Specific growth rate of bacterioplankton and coupling to phytoplankton in an oligotrophic lake. Limnology and Oceanography 40: pp. $1187-1200$.

[11] Le J, Wehr JD, and Campbell L, 1994. Uncoupling of bacterioplankton and phytoplankton production in fresh waters is affected by inorganic nutrient limitation. Applied Environmental Microbiology. 60: pp. 2089 - 2093.

[12] Rier ST, and Stevenson RJ, 2001, Relation of environmental factors to density of epilithic lotic bacteria in 2 ecoregions. North American Benthological Society 20: pp. 520 - 532.

[13] Coffin RB, and Sharp JH, 1987. Bacterial production in fresh and salt water ecosystems: a cross system overview. Marine Ecology Progress Series 43: pp. 1 - 10.

[14] Findlay S, Pace ML, David L, and Cole JJ, 1991. Weak coupling of bacterial and algal production in a heterotrophic ecosystem: The Hudson River estuary. Limnology and Oceanography 36: pp. $268-278$.

[15] Findlay S, Howe K, and Fontvielle D, 1993. Bacterial-algal relationship in streams of the Hubbard Brook Experimental Forest. Ecology 74: pp. 2326 - 2336.

[16] Fuhrman JA, Sleeter TD, Carlson CA, and Proctor LM, 1989. Dominance of bacterial biomass in the Sargasso Sea and its ecological implications. Marine Ecology Progress Series 57: pp. $207-217$.

[17] Cho, BC, and Azam F, 1990. Biogeochemical significance of bacterial biomass in the ocean's euphotic zone. Marine Ecology Progress Series 63: pp. $253-259$.

[18] Rier ST, and Stevenson RJ, 2002. Effects of light dissolved organic carbon, and inorganic nutrients on the relationship between algae and heterotrophic bacteria stream periphyton. Hydrobiologia 489: pp. 179 - 184.

[19] Geesey G, Mutch R, and Costerton JW, Green RB, 1978. Sessile bacteria: An important component of the microbial population in a small mountain stream. Limnology and Oceanography 23: pp.1214-1223.

[20] Nawa IG, 1982. An ecological study of the Cross River Estuary. $\mathrm{PhD}$ Thesis, University of Kiel. F.R. Germany. 162pp.

[21] Enyenihi UK, 1991. The Cross River Basin: Soil Characteristics, Geology, Climate, Hydrology \& Pollution, International Workshop on Methodology \& Quantitative Assessment of Pollution Load of Coastal Environment (FAO/UNAP/IOC/WHO), 17pp.

[22] Akpan ER, 1994. Seasonal variation in phytoplankton biomass in relation to physicochemical factors in Cross River Estuary of South Eastern Nigeria, PhD thesis, University of Calabar. 
[23] Asuquo FE, 1998. Physiochemical characteristics and Anthropogenic Pollution of the surface water of Calabar River, Nigeria. Global Journal of Pure \& Applied Science 5: pp.595 600 .

[24] Lowenberg U, and Kunzel T, 1991. Investigation on the Trawl Fishery of the Cross River Estuary, Nigeria. Journal of Applied Ichthyology 7: pp.44-53.

[25] APHA, Standard Methods for the Examination of Water Waste Water, American Public and Health Association, American Water, Works Association and Water Environment Federation (WEF), 20th edition, 1998.

[26] Feig YS, and Porter KG, 1980. The use of DAPI for identification and counting aquatic microflora. Limnology and Oceanography 25: pp.943-948

[27] Inyang AI, Sunday KE, and Nwankwo, DI, 2015. Composition of Periphyton Community on Water Hyacinth (Eichhornia crassipes): In Analysis of Environmental Characteristics at Ejirin Part of Epe Lagoon in Southwestern Nigeria. Journal of Marine Biology 2015: pp.1 - 9.
[28] Ratkowsky DA, Olley J, McMeekin TA, and Ball A, 1982. Relationship between temperature and growth rate of bacterial cultures. Journal of Bacteriology 149: pp.1-5

[29] Adams HE, Crump BC, and Kling GW, 2010. Temperature controls on aquatic bacterial production and community dynamics in arctic lakes and streams. Environmental Microbiology 12: pp.1319-1333.

[30] Brown CD, Hoyer MV, Bachmann RW, and Canfield DE Jr. 2000. Nutrient-chlorophyll a relationships: an evaluation of empirical nutrient-chlorophyll a models using Florida and northern temperate lake data. Canadian Journal of Fisheries and Aquatic Sciences 57: pp.1574 - 1583.

[31] Larson U, and Hagstron A, 1979. Phytoplankton exudates release an energy source for the growth of pelagic bacteria. Marine Biology 52: pp.199 - 206.

[32] Mague T, Friberg E, Hughes DJ, and Morris I, 1980. Extracellular release of carbon by marine phytoplankton: a physiological approach. Limnology and Oceanography 25: pp. $262-279$. 